\author{
Supporting Information for \\ Atropisomers of meso-Conjugated Uracyl Porphyrin Derivatives \\ and their Assembling Structures \\ Satoshi Arai, Daisuke Niwa, Hiroyuki Nishide and Shinji Takeoka \\ Department of Applied Chemistry, Waseda University \\ 3-4-1 Okubo, Shinjuku-ku, Tokyo 169-8555.
}

\title{
Contents
}

General method

Synthesis of 2, 3, 4 and $\mathbf{5}$ (S2-S4)

NMR spectra of compound $\mathbf{2}, \mathbf{4}, \mathbf{5} \alpha \alpha$, and $\mathbf{5} \alpha \beta$ (S5-S9)

${ }^{1} \mathrm{H}$ NMR spectra of the mixture with Mela and $\mathbf{5} \alpha \alpha$ or $\mathbf{5} \alpha \beta(\mathrm{S} 10-\mathrm{S} 11)$

2D NMR (DOSY) (S11-S12)

The addition of the imidazole to $\mathbf{5} \alpha \boldsymbol{\alpha}$-Mela dimer (S13)

The dilution experiment of the mixture $5 \alpha \alpha(\mathbf{Z n})$-Mela in toluene (S14)

UV-vis spectra of the mixed solution with Mela and $\mathbf{5} \alpha \alpha$ or $\mathbf{5} \alpha \beta$ (S14) 
General methods. 5-Formyl-6-methyluracil 1 and 3-hexyl-4-methylbenzylpyrrole were synthesized according to the previous literature ${ }^{1}$. All solvents were purchased from Kanto Chemical Industry Co. $\mathrm{CH}_{2} \mathrm{Cl}_{2}$ was distilled from $\mathrm{P}_{2} \mathrm{O}_{5}$. THF was distilled using sodium wire. Other solvents, including deuterated solvents, were used as received. Lewis acid $\left(\mathrm{BF}_{3} \mathrm{OEt}_{2}\right)$ was used as received and while fresh. All organic reagents were purchased from Tokyo Kasei Kogyo Co. Ltd., and used without further purification. All synthesized compounds were characterized by ${ }^{1} \mathrm{H}$ NMR and mass spectrometry (FAB, or ESI); if necessary, further detailed characterization was performed using COSY and NOESY. NMR spectra were recorded on a JEOL JNM-LA500 (500 $\mathrm{MH}_{\mathrm{Z}}$ for $\left.{ }^{1} \mathrm{H}\right)$ with chemical shifts $(\delta)$ downfield from tetramethylsilane as the internal standard. Infrared analyses were performed as a film on a $\mathrm{NaCl}$ crystal plate, using a JASCO FT-IR 5300 spectrometer. Plastic sheets coated with $0.2 \mathrm{~mm}$ silica gel 60 without a fluorescent indicator (Merck) were used for thin-layer chromatography.

\section{Synthetic compounds.}

Synthesis of 1-Ethoxymethyl-5-formyl-6-methyluracil 2

Bis(trimethylsilyl) acetamide $(3.3 \mathrm{~g}, 16 \mathrm{mmol})$ was dissolved in dry THF (130 ml), followed by the addition of 5-formyl-6-methyluracil (1.0 g, $6.5 \mathrm{mmol})$. After ten min., chloromethylethyl ether $(0.92 \mathrm{~g}, 9.7 \mathrm{mmol})$ and CsI $(1.7 \mathrm{~g}, 6.5 \mathrm{mmol})$ were added to the solution, followed by stirring at amibient temperature for 1 day. The reaction was quenched by sat. $\mathrm{NaHCO}_{3}(100 \mathrm{ml})$. The aqueous phase was extracted by EtOAc three times. The combined organic phases were dried with $\mathrm{MgSO}_{4}$. After evaporation, the residue was purified by column chromathography (silica gel; $\mathrm{CHCl}_{3} / \mathrm{MeOH}=10 / 1$ $(\mathrm{v} / \mathrm{v}))$ to give 2 as viscous brown liquid; yield $0.42 \mathrm{~g}(30 \%) .{ }^{1} \mathrm{H}$ NMR (500 MHz, $\left.\mathrm{CDCl}_{3}\right): \delta=10.5(\mathrm{~s}, 1 \mathrm{H}, \mathrm{NH}), 10.1(\mathrm{~s}, 1 \mathrm{H}, \mathrm{CHO}), 5.40\left(\mathrm{~s}, 2 \mathrm{H}, \mathrm{NCH}_{2}\right), 3.55$ (q, $J=7.0$ $\left.\mathrm{Hz}, 2 \mathrm{H}, \mathrm{OCH}_{2} \mathrm{CH}_{3}\right), 2.76\left(\mathrm{~s}, 3 \mathrm{H}, \mathrm{CH}_{3}\right), 1.08\left(\mathrm{t}, J=7.0 \mathrm{~Hz}, 3 \mathrm{H}, \mathrm{CH}_{2} \mathrm{CH}_{3}\right) ;{ }^{13} \mathrm{C} \mathrm{NMR}$ (500 $\left.\mathrm{MHz}, \quad \mathrm{CDCl}_{3}\right): \delta=189.1,163.4,163.3,150.6,108.9,72.9$, 65.3, 15.2, 14.8; ESI-MS, m/z 212.3 (found $\mathrm{M}^{+}$), 212.1 (calcd.) Anal. Calcd. for $\mathrm{C}_{9} \mathrm{H}_{12} \mathrm{~N}_{2} \mathrm{O}_{4}$ : C, 50.94; H, 5.70\%. Found: C, 50.80; H, 5.50\%.

\section{Synthesis of dipyrrolmethane 4}

5-Formyluracil derivative $2(0.67 \mathrm{~g}, 3.2 \mathrm{mmol})$ and 3-hexyl-4-methylbenzylpyrrole $(2.1 \mathrm{~g}, 7.0 \mathrm{mmol})$ were dissolved in $\mathrm{CH}_{2} \mathrm{Cl}_{2}(320 \mathrm{ml})$. After purging with argon gas for $15 \mathrm{~min}$., $\mathrm{BF}_{3} \mathrm{OEt}_{2}(80 \mu \mathrm{l}, 0.63 \mathrm{mmol})$ was added to the solution and stirred at 
amibient temperature for $40 \mathrm{hr}$. After the solution was evaporated, the residue was purified by column chromatography ( viscous orange liquid; yield $1.70 \mathrm{~g}(68 \%)$. The dipyrrolmethane 3 and $\mathrm{Pd} / \mathrm{C}(100 \mathrm{mg})$ were added in THF $(30 \mathrm{ml})$ and ethanol $(10 \mathrm{ml})$, and hydrogen gas was bubbled through the solution at r.t. until the spot of $\mathbf{3}$ was non-detectable by TLC. The solution was filtered through Celite and concentrated to dryness to give 4 as white solid; yield $1.26 \mathrm{~g}$ (93\%). ${ }^{1} \mathrm{H}$ NMR (500 MHz, DMSO-d 6 ): $\delta=12.0$ (brs, 2H, COOH), 11.7 (s, 1H, NH), $10.1(\mathrm{~s}, 2 \mathrm{H}, \mathrm{NH}), 5.54(\mathrm{~s}, 1 \mathrm{H}, \mathrm{CH}), 5.44\left(\mathrm{~s}, 2 \mathrm{H}, \mathrm{NCH}_{2}\right), 3.55(\mathrm{q}, J=7.0 \mathrm{~Hz}, 2 \mathrm{H}$, $\left.\mathrm{OCH}_{2} \mathrm{CH}_{3}\right), 2.61$ (t, J=7.0 Hz, 4H, py-CH$)_{2}, 2.42\left(\mathrm{~s}, 3 \mathrm{H}, \mathrm{CH}_{3}\right), 1.78\left(\mathrm{~s}, 6 \mathrm{H}, \mathrm{CH}_{3}\right), 1.38$ (m, 4H, py- $\left.\mathrm{CH}_{2} \mathrm{CH}_{2}\right), 1.25\left(\mathrm{~m}, 12 \mathrm{H}, \mathrm{CH}_{2}\right), 1.05$ (t, $\left.J=7.0 \mathrm{~Hz}, 3 \mathrm{H}, \mathrm{OCH}_{2} \mathrm{CH}_{3}\right), 0.84$ (t, $6 \mathrm{H}, J=6.5 \mathrm{~Hz}, \mathrm{CH}_{3}$ ); ESI-MS, m/z 635.4 (found $\mathrm{M}+\mathrm{Na}^{+}$), 612.4 (calcd.) Anal. Calcd for $\mathrm{C}_{33} \mathrm{H}_{48} \mathrm{~N}_{4} \mathrm{O}_{7}$ : C, 64.68; H, 7.90\%. Found: $\mathrm{C}, 65.10 ; \mathrm{H}, 8.01 \%$.

\section{Synthesis of porphyrin $\mathbf{5}$}

A mixture of dipyrrolmethane $4(1.10 \mathrm{~g}, 1.75 \mathrm{mmol})$, trimethyl orthoformate $(2.01$ $\mathrm{ml}, 18.4 \mathrm{mmol})$ and trichloroacetic acid $(8.57 \mathrm{~g}, 52.5 \mathrm{mmol})$ was dissolved in dry $\mathrm{CH}_{2} \mathrm{Cl}_{2} 350 \mathrm{ml}$ (THF $0.5 \%$ ) and stirred at amibient temperature for 4 days. The solution was washed with water three times and extracted with $\mathrm{CH}_{2} \mathrm{Cl}_{2}$. The combined organic phase was dried with $\mathrm{Na}_{2} \mathrm{SO}_{4}$. The residue was carefully purified by column chromatography (silica gel; $\mathrm{CHCl}_{3} / \mathrm{MeOH}=40 / 1$ (TEA 2\%)). $\quad 5 \alpha \beta:{ }^{1} \mathrm{H}$ NMR (500 $\mathrm{MHz}, \mathrm{CDCl}_{3}$ ): $\delta=10.19$ (s, 2H, meso), 8.65 (s, 2H, NH), 5.66 (s, 4H, $\mathrm{NCH}_{2}$ ), 4.02 (t, $J$ $\left.=8.0 \mathrm{~Hz}, 8 \mathrm{H}, \mathrm{py}-\mathrm{CH}_{2}\right), 3.92\left(\mathrm{q}, J=7.0 \mathrm{~Hz}, 4 \mathrm{H}, \mathrm{OCH}_{2} \mathrm{CH}_{3}\right), 3.16\left(\mathrm{~s}, 12 \mathrm{H}, \mathrm{CH}_{3}\right), 2.21(\mathrm{~m}$, $8 \mathrm{H}$, py- $\left.\mathrm{CH}_{2} \mathrm{CH}_{2}\right), 1.95\left(\mathrm{~s}, 6 \mathrm{H}, \mathrm{CH}_{3}\right), 1.78$ (m, 8H, py- $\left.\mathrm{CH}_{2} \mathrm{CH}_{2} \mathrm{CH}_{2}\right), 1.50$ (m, 8H, py- $\mathrm{CH}_{2} \mathrm{CH}_{2} \mathrm{CH}_{2} \mathrm{CH}_{2}$ ), $1.38\left(\mathrm{~m}, 14 \mathrm{H}, \mathrm{OCH}_{2} \mathrm{CH}_{3}, \mathrm{CH}_{2}\right.$ ), 0.92 (t, $\mathrm{J}=7.5 \mathrm{~Hz}, 12 \mathrm{H}, \mathrm{CH}_{3}$ ), -2.42 (s, 2H, innerNH) ${ }^{1} \mathrm{H}$ NMR (500 MHz, DMSO-d 6 ): $\delta=10.31$ (s, 2H, meso), 5.72 (s, $\left.4 \mathrm{H}, \mathrm{NCH}_{2}\right), 4.16\left(\mathrm{t}, J=7.5 \mathrm{~Hz}, 8 \mathrm{H}, \mathrm{py}-\mathrm{CH}_{2}\right), 3.88\left(\mathrm{q}, J=7.0 \mathrm{~Hz}, 4 \mathrm{H}, \mathrm{OCH}_{2} \mathrm{CH}_{3}\right), 3.22$ $\left(\mathrm{s}, 12 \mathrm{H}, \mathrm{CH}_{3}\right), 2.29\left(\mathrm{~m}, 8 \mathrm{H}, \mathrm{py}-\mathrm{CH}_{2} \mathrm{CH}_{2}\right), 1.97\left(\mathrm{~s}, 6 \mathrm{H}, \mathrm{CH}_{3}\right), 1.84(\mathrm{~m}, 8 \mathrm{H}$, py- $\left.\mathrm{CH}_{2} \mathrm{CH}_{2} \mathrm{CH}_{2}\right), \quad 1.55$ (m, $8 \mathrm{H}, \quad$ py- $\left.\mathrm{CH}_{2} \mathrm{CH}_{2} \mathrm{CH}_{2} \mathrm{CH}_{2}\right), \quad 1.46 \quad(\mathrm{~m}, \quad 8 \mathrm{H}$, py- $\mathrm{CH}_{2} \mathrm{CH}_{2} \mathrm{CH}_{2} \mathrm{CH}_{2} \mathrm{CH}_{2}$ ), 1.38 (t, $\left.J=7.0 \mathrm{~Hz}, 6 \mathrm{H}, \mathrm{OCH}_{2} \mathrm{CH}_{3}\right), 0.96$ (t, $J=7.4 \mathrm{~Hz}, 12 \mathrm{H}$, $\mathrm{CH}_{3}$ ), -2.50 (s, 2H, innerNH); ESI-MS, m/z 1088.7 (found $\mathrm{M}+\mathrm{Na}^{+}$), 1066.7 (calcd.) Anal. Calcd. for $\mathrm{C}_{64} \mathrm{H}_{90} \mathrm{~N}_{8} \mathrm{O}_{6}$ : C, 72.01; H, 8.50\%. Found: C, 73.02; H, 9.01\%; $\mathrm{UV}\left(\mathrm{CHCl}_{3}\right) \lambda(\mathrm{nm})=410,509,542,577,629 ; 5 \alpha \alpha:{ }^{1} \mathrm{H}$ NMR $\left(500 \mathrm{MHz}, \mathrm{CDCl}_{3}\right)$ : $\delta=10.19\left(\mathrm{~s}, 2 \mathrm{H}\right.$, meso), $8.64(\mathrm{~s}, 2 \mathrm{H}, \mathrm{NH}), 5.63\left(\mathrm{~s}, 4 \mathrm{H}, \mathrm{NCH}_{2}\right), 4.02(\mathrm{t}, J=7.5 \mathrm{~Hz}, 8 \mathrm{H}$, py- $\mathrm{CH}_{2}$ ), 3.91 (q, $\left.J=7.0 \mathrm{~Hz}, 4 \mathrm{H}, \mathrm{OCH}_{2} \mathrm{CH}_{3}\right), 3.17\left(\mathrm{~s}, 12 \mathrm{H}, \mathrm{CH}_{3}\right), 2.21(\mathrm{~m}, 8 \mathrm{H}$, py- $\left.\mathrm{CH}_{2} \mathrm{CH}_{2}\right), 1.81\left(\mathrm{~s}, 6 \mathrm{H}, \mathrm{CH}_{3}\right), 1.75\left(\mathrm{~m}, 8 \mathrm{H}\right.$, py- $\left.\mathrm{CH}_{2} \mathrm{CH}_{2} \mathrm{CH}_{2}\right), 1.50(\mathrm{~m}, 8 \mathrm{H}$, py- $\mathrm{CH}_{2} \mathrm{CH}_{2} \mathrm{CH}_{2} \mathrm{CH}_{2}$ ), 1.35 (m, $14 \mathrm{H}, \mathrm{OCH}_{2} \mathrm{CH}_{3}, \mathrm{CH}_{2}$ ), 0.91 (t, $\mathrm{J}=7.6 \mathrm{~Hz}, 12 \mathrm{H}, \mathrm{CH}_{3}$ ), 
-2.42 (s, 2H, innerNH) ${ }^{1} \mathrm{H}$ NMR (500 MHz, DMSO-d 6 ): $\delta=12.24(\mathrm{~s}, 2 \mathrm{H}, \mathrm{NH}), 10.28(\mathrm{~s}$, 2H, meso), 5.67 (s, 4H, $\mathrm{NCH}_{2}$ ), 4.13 (m, 8H, py-CH $), 3.85$ (q, $J=7.0 \mathrm{~Hz}, 4 \mathrm{H}$, $\left.\mathrm{OCH}_{2} \mathrm{CH}_{3}\right), 3.20\left(\mathrm{~s}, 12 \mathrm{H}, \mathrm{CH}_{3}\right), 2.24\left(\mathrm{~m}, 8 \mathrm{H}, \mathrm{py}-\mathrm{CH}_{2} \mathrm{CH}_{2}\right), 1.84\left(\mathrm{~s}, 6 \mathrm{H}, \mathrm{CH}_{3}\right), 1.77(\mathrm{~m}$, $8 \mathrm{H}$, py- $\left.\mathrm{CH}_{2} \mathrm{CH}_{2} \mathrm{CH}_{2}\right), \quad 1.54\left(\mathrm{~m}, \quad 8 \mathrm{H}, \quad\right.$ py- $\left.\mathrm{CH}_{2} \mathrm{CH}_{2} \mathrm{CH}_{2} \mathrm{CH}_{2}\right), \quad 1.42 \quad(\mathrm{~m}, \quad 8 \mathrm{H}$, py- $\mathrm{CH}_{2} \mathrm{CH}_{2} \mathrm{CH}_{2} \mathrm{CH}_{2} \mathrm{CH}_{2}$ ), 1.38 (t, $J=7.0 \mathrm{~Hz}, 6 \mathrm{H}, \mathrm{OCH}_{2} \mathrm{CH}_{3}$ ), 0.92 (t, $J=7.4 \mathrm{~Hz}, 12 \mathrm{H}$, $\mathrm{CH}_{3}$ ), -2.54 (s, 2H, innerNH); ESI-MS, m/z 1088.7 (found $\mathrm{M}+\mathrm{Na}^{+}$), 1066.7 (calcd.) Anal. Calcd for $\mathrm{C}_{64} \mathrm{H}_{90} \mathrm{~N}_{8} \mathrm{O}_{6}$ : C, 72.01; H, 8.50\%. Found: C, 73.01; H, 8.99\%; $\mathrm{UV}\left(\mathrm{CHCl}_{3}\right) \lambda(\mathrm{nm})=410,509,542,577,629$.

\section{Reference}

1. N. Ono, K. Maruyama, Bull. Chem. Soc. Jpn., 1988, 61, 4470., Petersen L., Pedersen E. B., Nielsen C. Synthesis, 2001, 4, 559. 
Figure S1. ${ }^{1} \mathrm{H}$ NMR spectra of compound 2

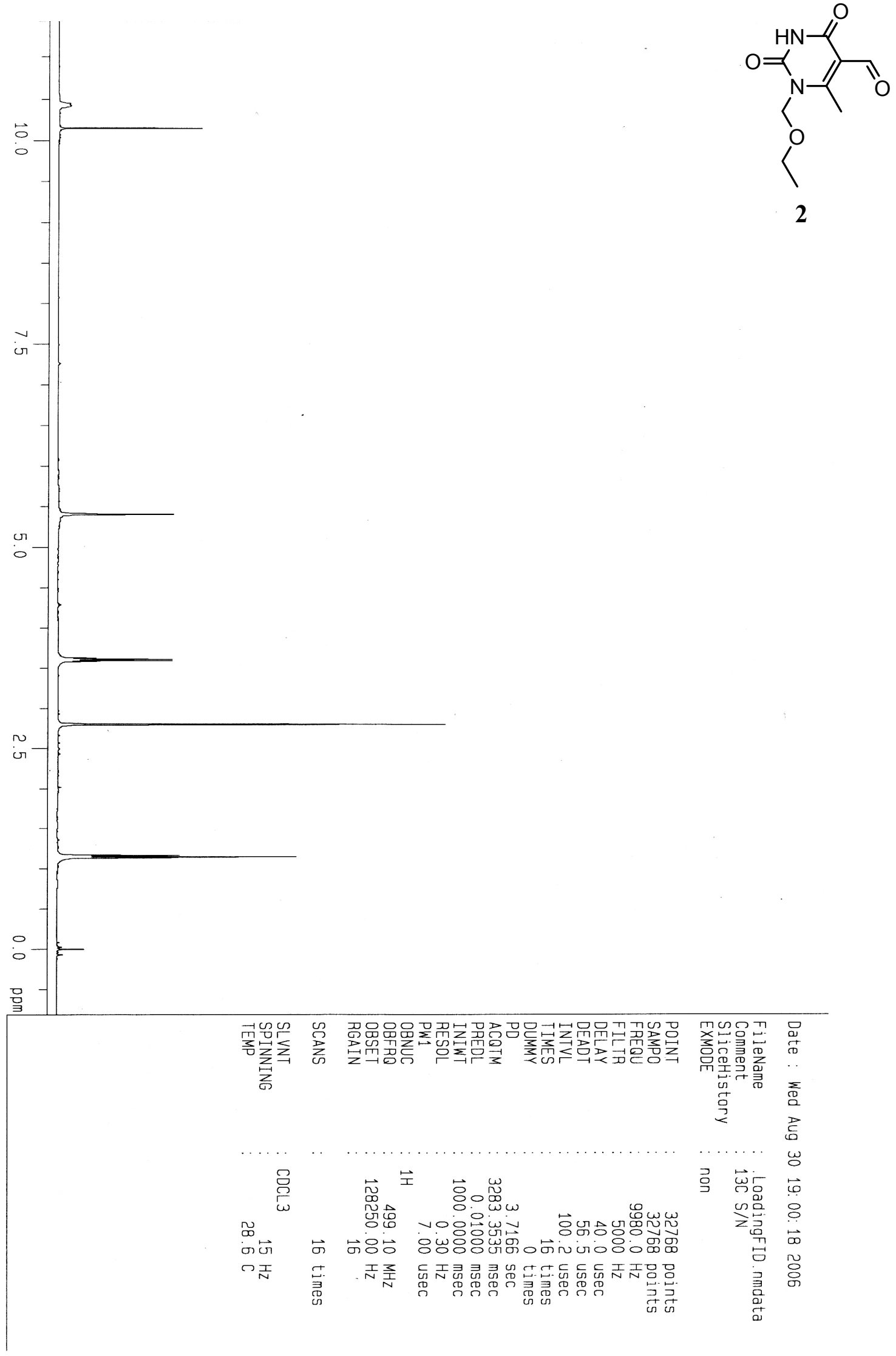


Figure S2. ${ }^{13} \mathrm{C}$ NMR spectra of compound 2

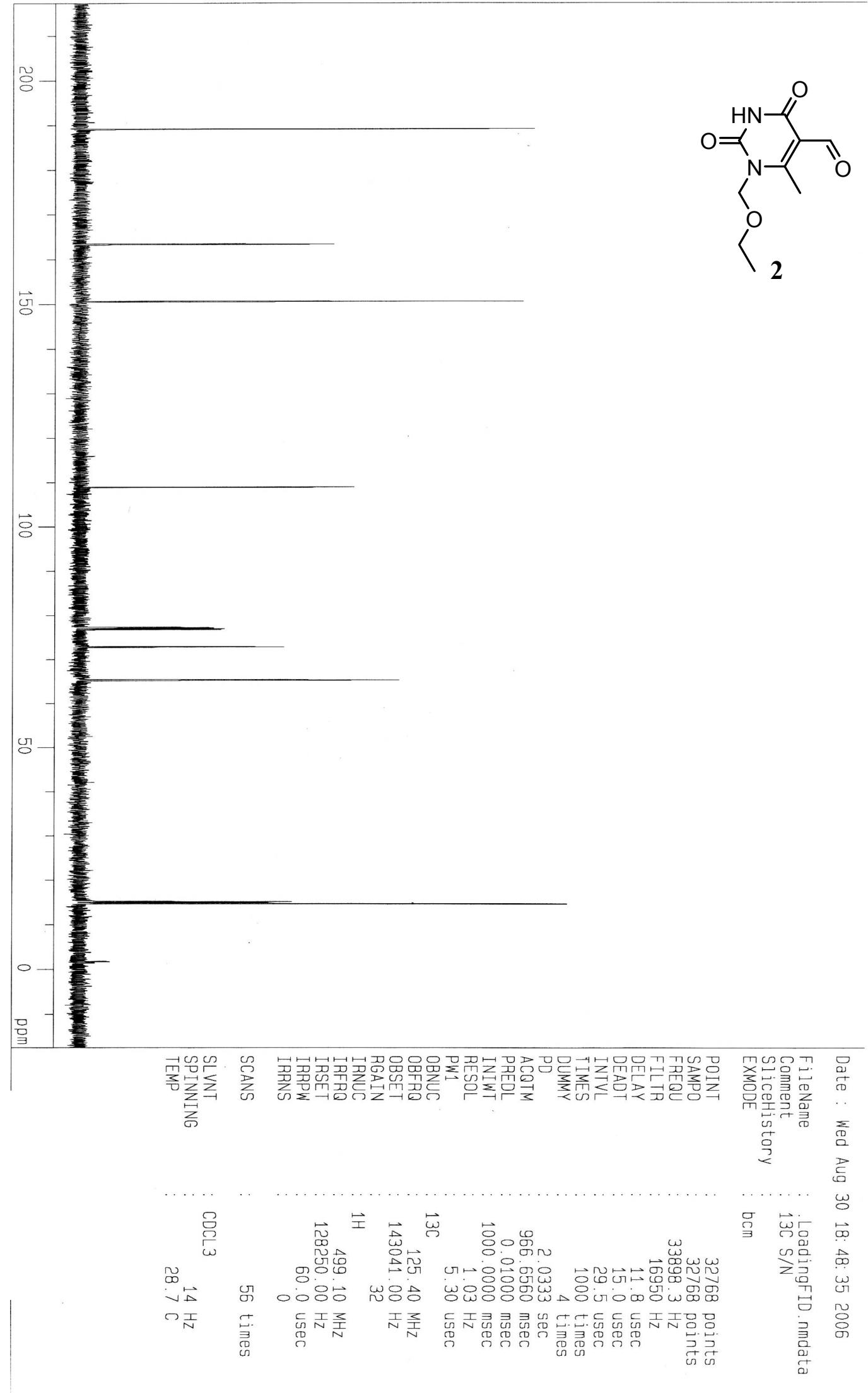




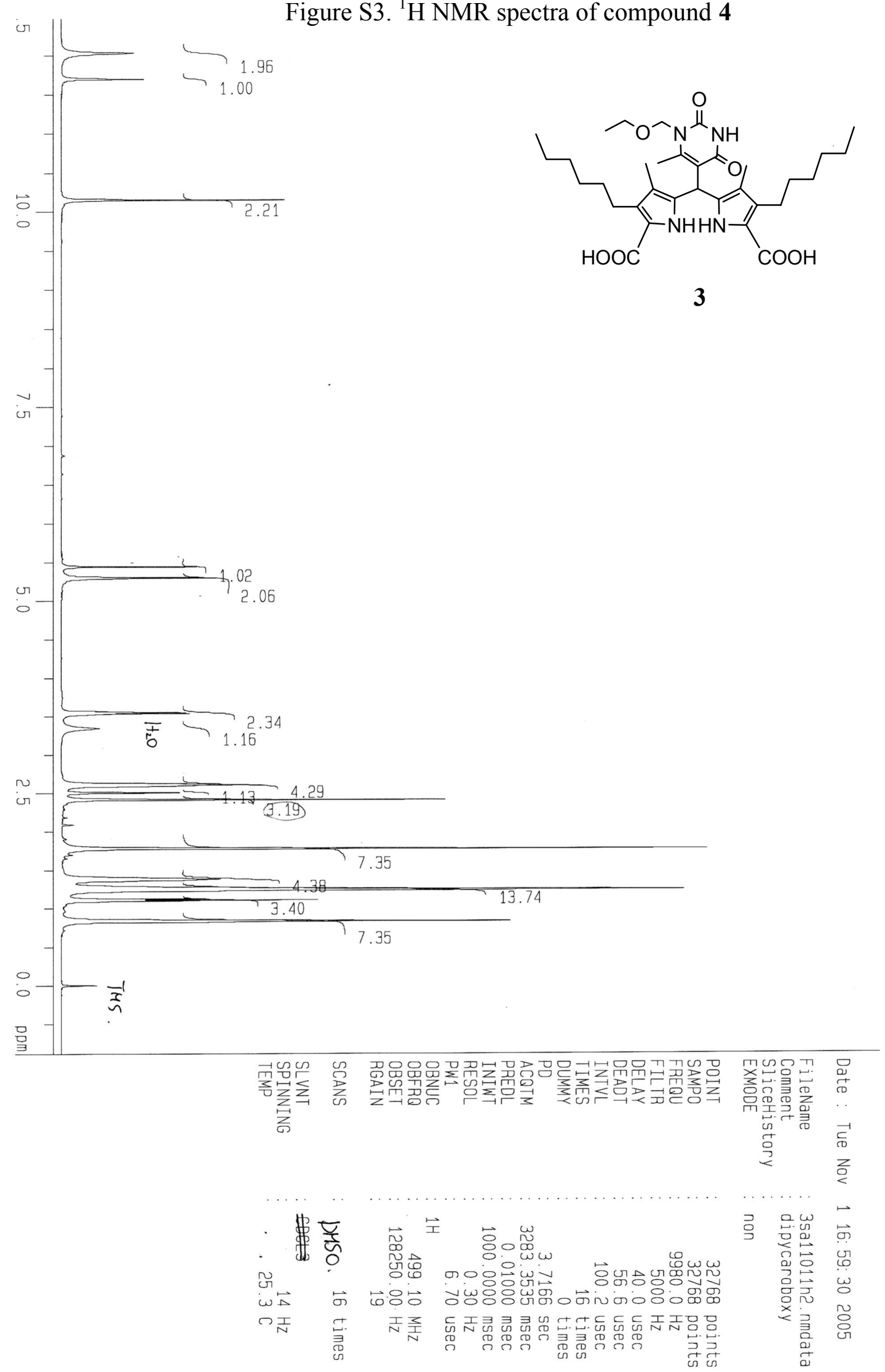


Figure S4. ${ }^{1} \mathrm{H}$ NMR spectra of the compound $\mathbf{5} \alpha \boldsymbol{\alpha}$ in $\mathrm{CDCl}_{3}$

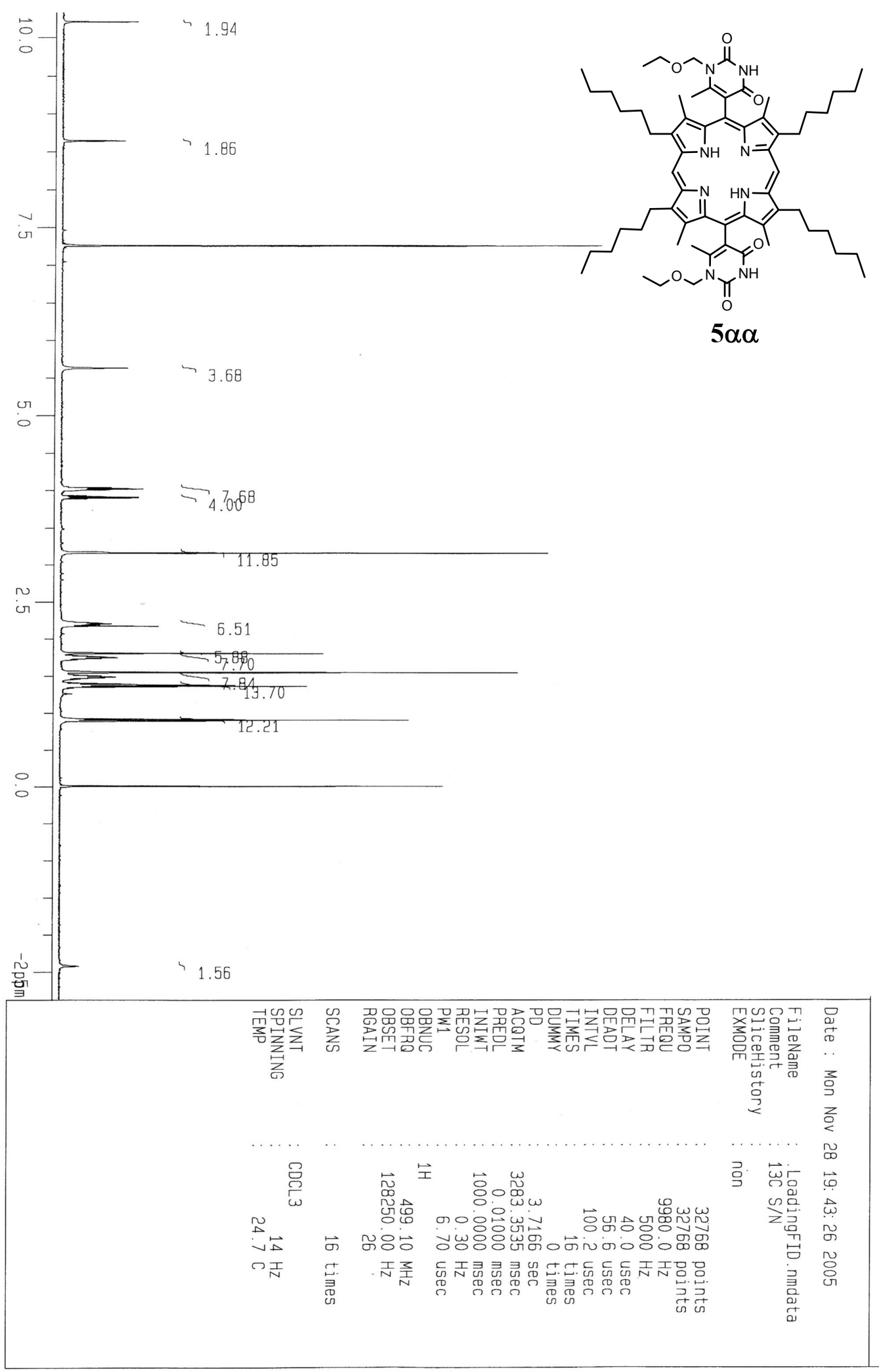


Figure S5. ${ }^{1} \mathrm{H}$ NMR spectra of the compound $\mathbf{5} \alpha \beta$ in

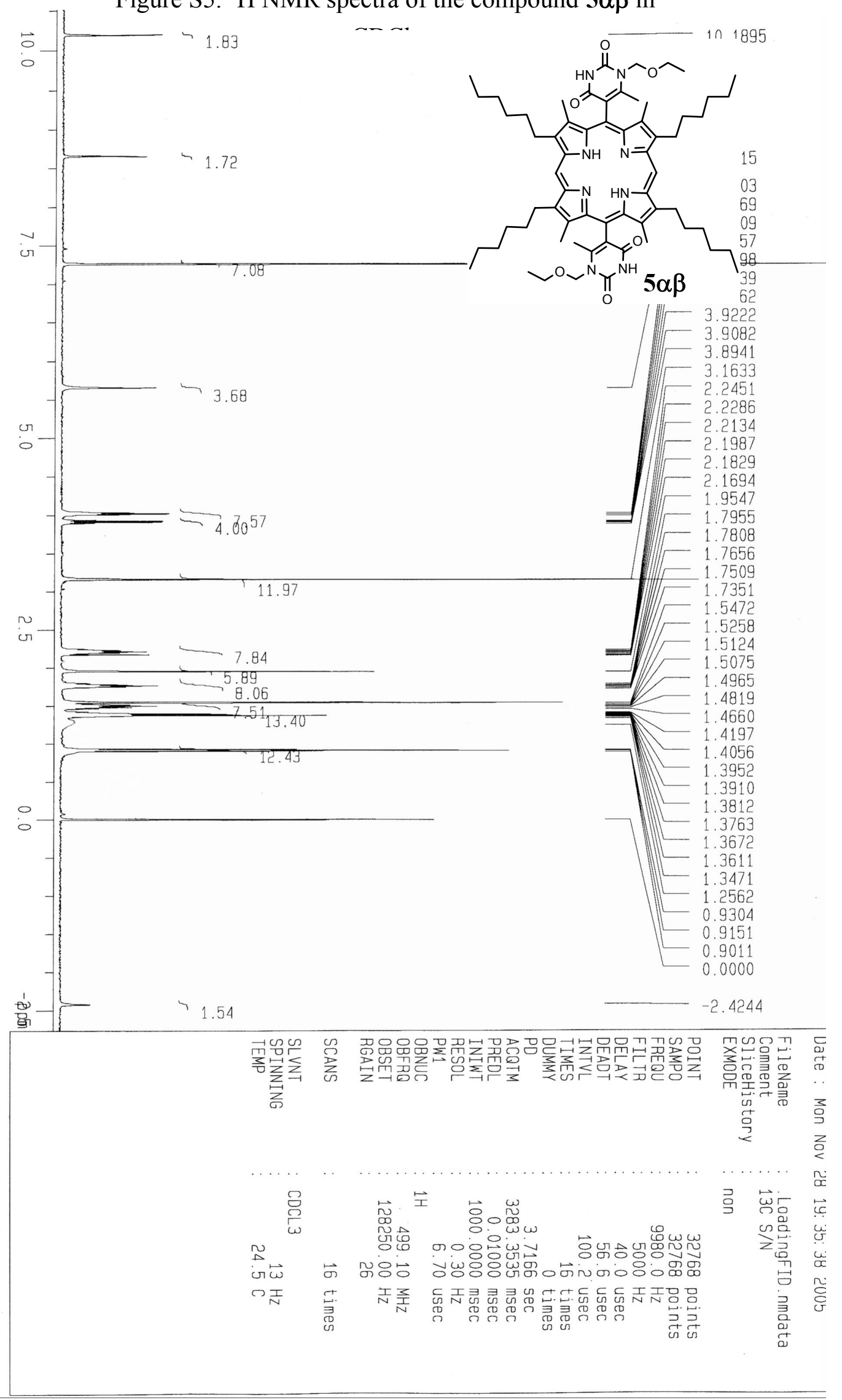


The mixed experiment with Mela and $5 \alpha \alpha$ or $5 \alpha \beta$

a) $5 \alpha \beta$-Mela $(25 \mathrm{mM})$ methine

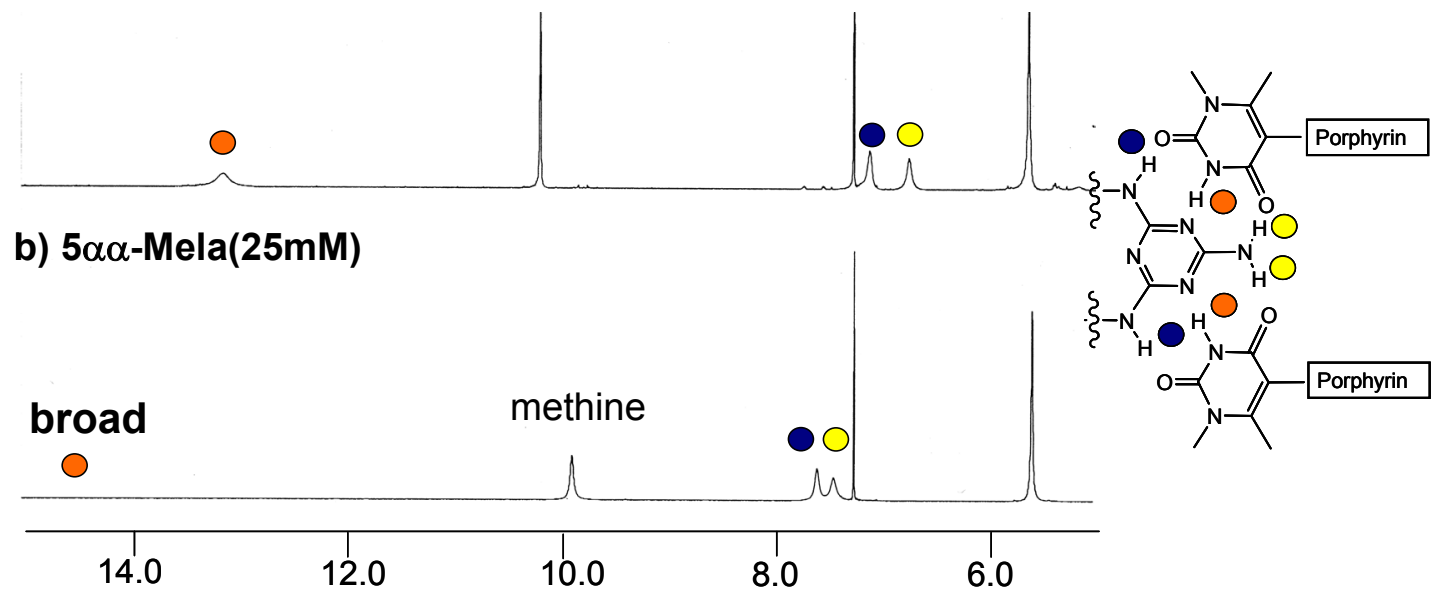

Figure S6. ${ }^{1} \mathrm{H}$ NMR spectra of the mixture with 5 and Mela in $\mathrm{CDCl}_{3}$.

The mixed experiment with $\mathbf{5} \alpha \beta$ and Mela

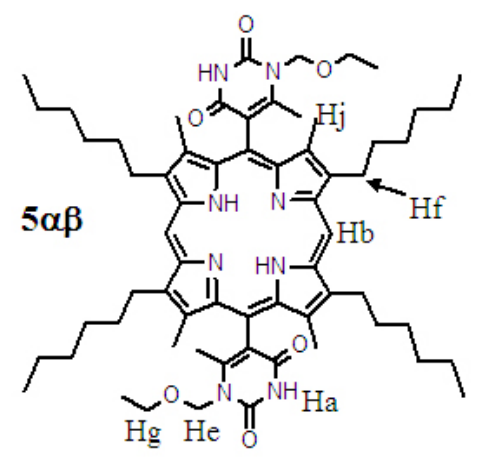

The degree of chemical

- shift compared to $\mathbf{5} \boldsymbol{\alpha} \boldsymbol{\beta}$

before addition of Mela

Hd

$\mathrm{H}_{2} \mathrm{~N}$

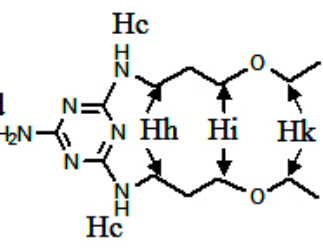

Mela
$\mathrm{Hb} \quad 0.02$ up
He 0.04 up
Hf $0.01 \mathrm{up}$
$\mathrm{Hg} \quad 0.04$ up
$\mathrm{Hj} \quad 0.00$

* "up" means that the signals of the proton showed upfield shift after addition of Mela.

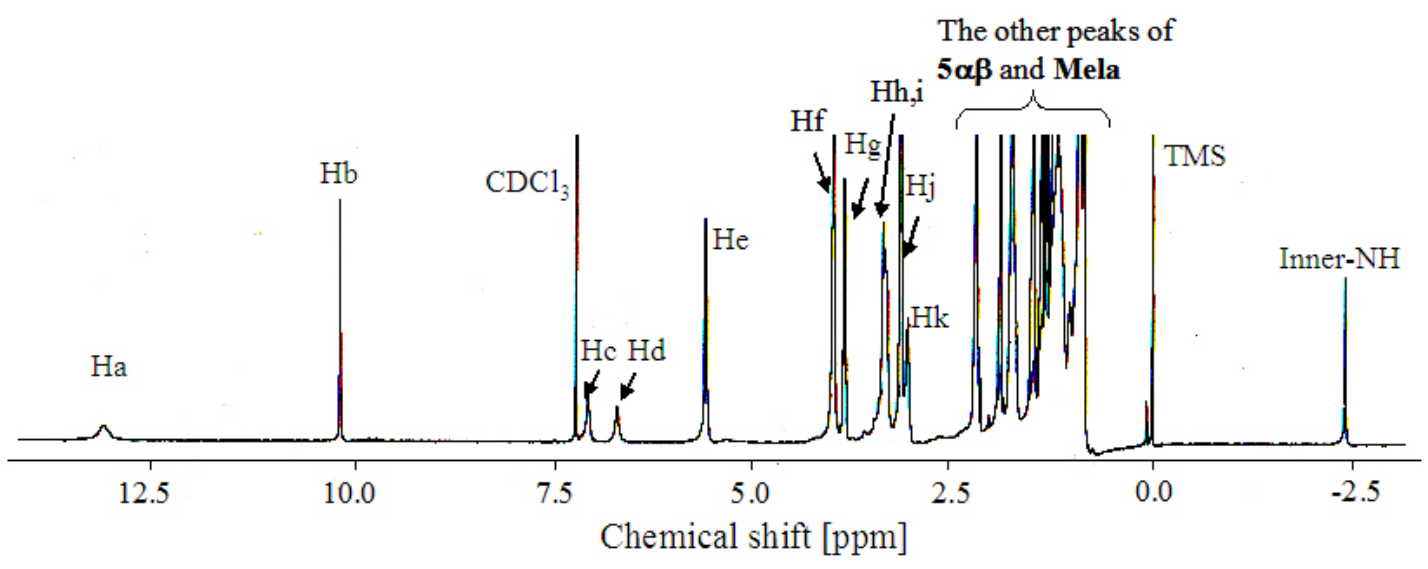

Figure S7. ${ }^{1} \mathrm{H}$ NMR spectra of the mixture of $5 \alpha \beta$ and Mela in $\mathrm{CDCl}_{3}$. 
The mixed experiment with $\mathbf{5} \alpha \alpha$ and Mela
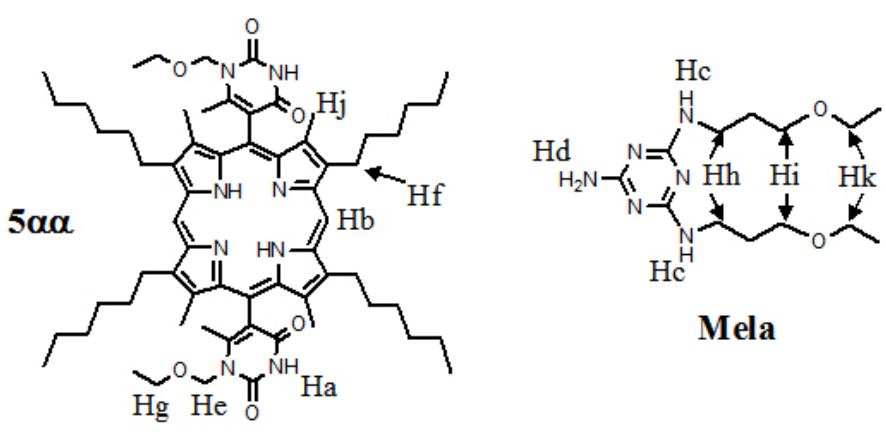

The degree of chemical

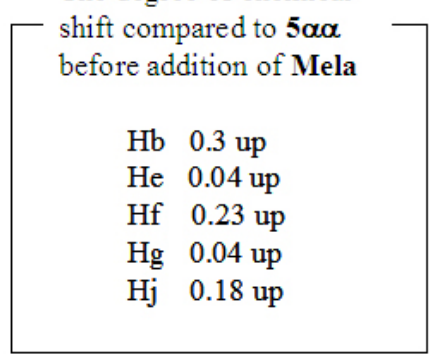

* "up" means that the signals of the proton showed upfield shift after addition of Mela.

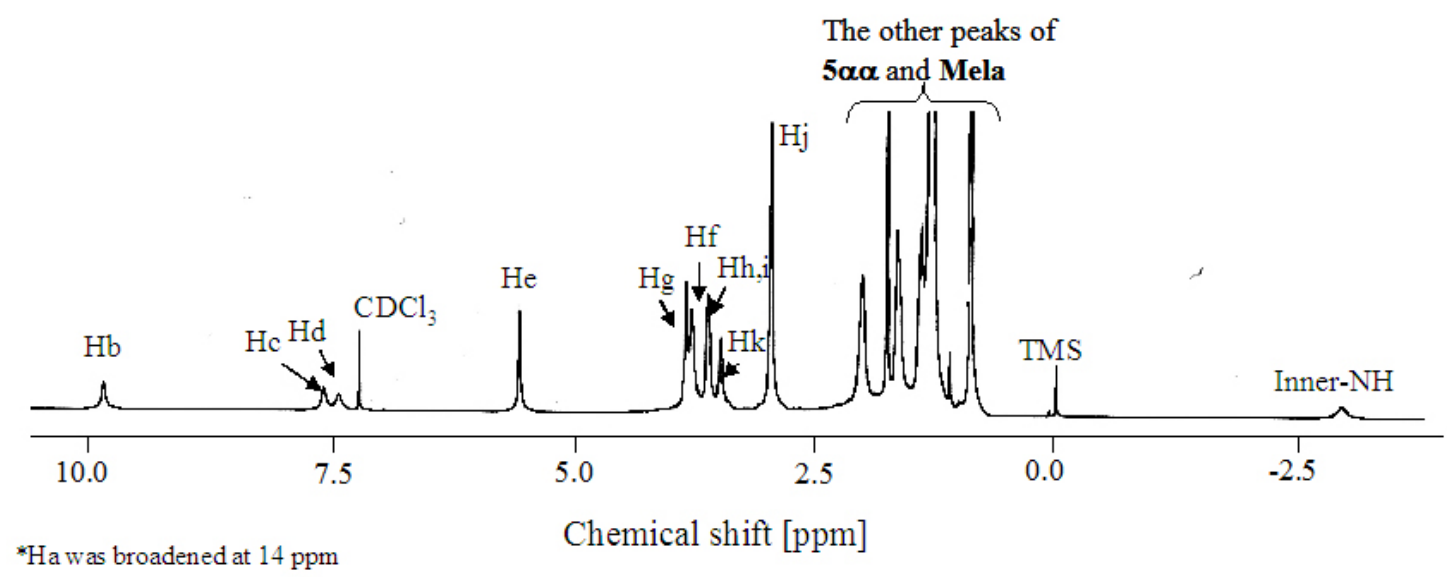

Figure S8. ${ }^{1} \mathrm{H}$ NMR spectra of the mixture o $5 \alpha \alpha$ and Mela in $\mathrm{CDCl}_{3}$.

\section{D-NMR (DOSY)}

2D NMR (DOSY) measurement was performed according to the previous report (Ohkawa H., Takayama A., Nakajima S., Nishide H. Org. Lett., 2006, 8, 2225.) at $300 \mathrm{~K}$ by a Bruker $600 \mathrm{MHz}$ NMR spectrometer. ${ }^{1} \mathrm{H}$ NMR diffusion measurements (DOSY) were performed without spinning. A diffusion coefficient was estimated by the software already-installed in Bruker NMR, where 20 data-points were analyzed for a curve-fitting. Diffusion coefficients of each sample were treated as a normalized diffusion coefficient, which was defined as a relative ratio to an internal standard. As an internal standard, heptakis(2,3,6-tri- $O$-methyl)- $\beta$-cyclodextrin $(\mathrm{M}=1429 \mathrm{~g} / \mathrm{mol})$ was used. For the calibration curve to evaluate a molecular weight from a normalized diffusion coefficient, $1 \mathrm{~mL}$ of $\mathrm{CDCl}_{3}$ solution containing $7.2 \mathrm{mg}$ of poly-styrene (PDI $<1.05, M n$ : 500, 1050, 2630, 5970, 9100), which is usually used for drawing a calibration curve on SEC, and $2 \mathrm{mg}$ of heptakis(2,3,6-tri-O-methyl)- $\beta$-cyclodextrin was applied. 


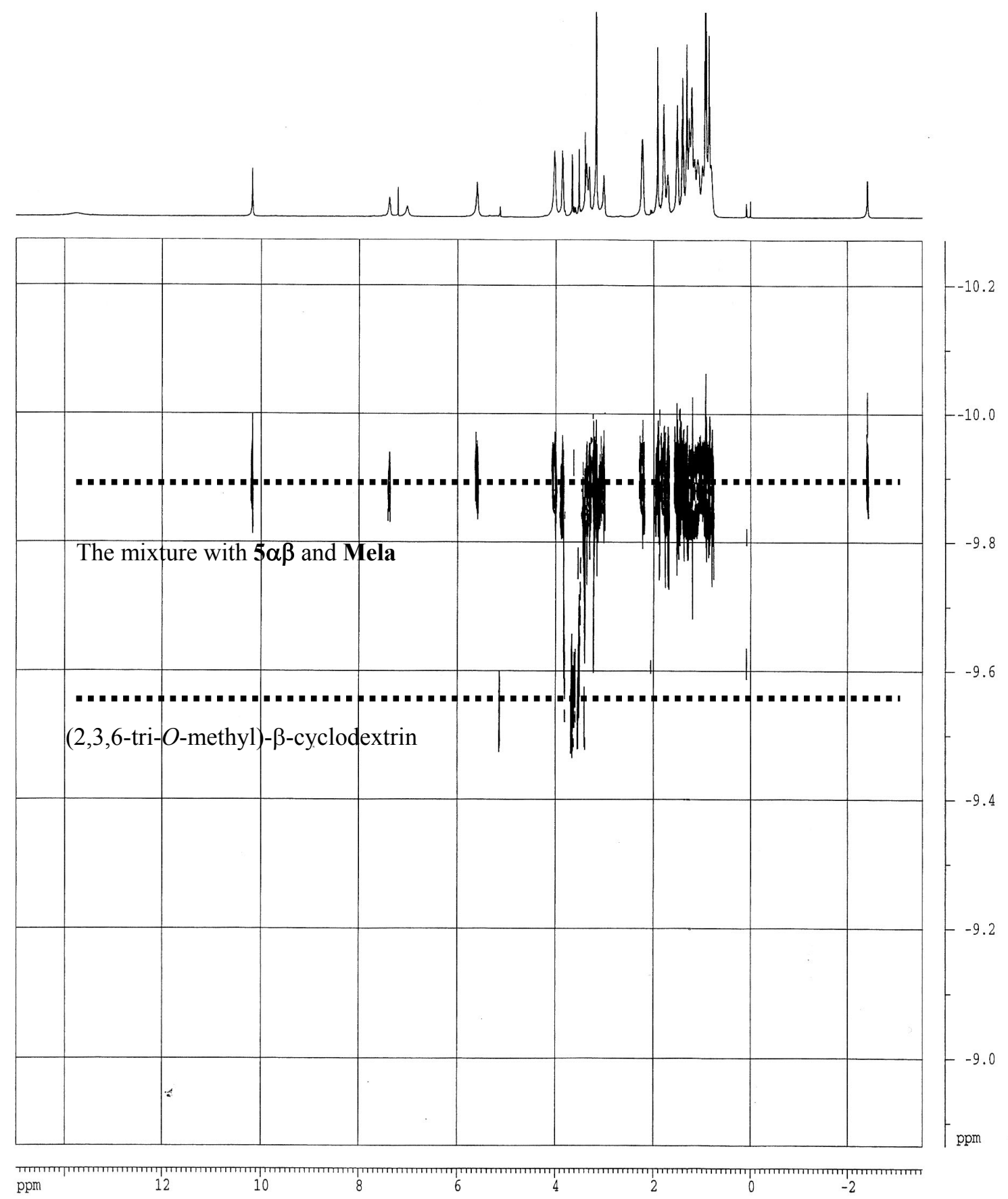

Figure S9. 2D-DOSY spectra of the mixed $\mathrm{CDCl}_{3}$ solution $(53 \mathrm{mM})$ with $\mathbf{5} \alpha \beta$ and Mela 
The addition of the benzylimidazole to 5 $\alpha \alpha$-Mela dimer

The toluene solution of the $\mathbf{5} \alpha \boldsymbol{\alpha}(\mathbf{Z n})$ and Mela $(1 \mathrm{mM})$ was mixed to prepare the dimer, and the stock solution of 3,5-dimethoxybenzylimidazole was added to the solution gradually. By the equimolar addition of the imidazole, the binding of the two imidazole was confirmed.

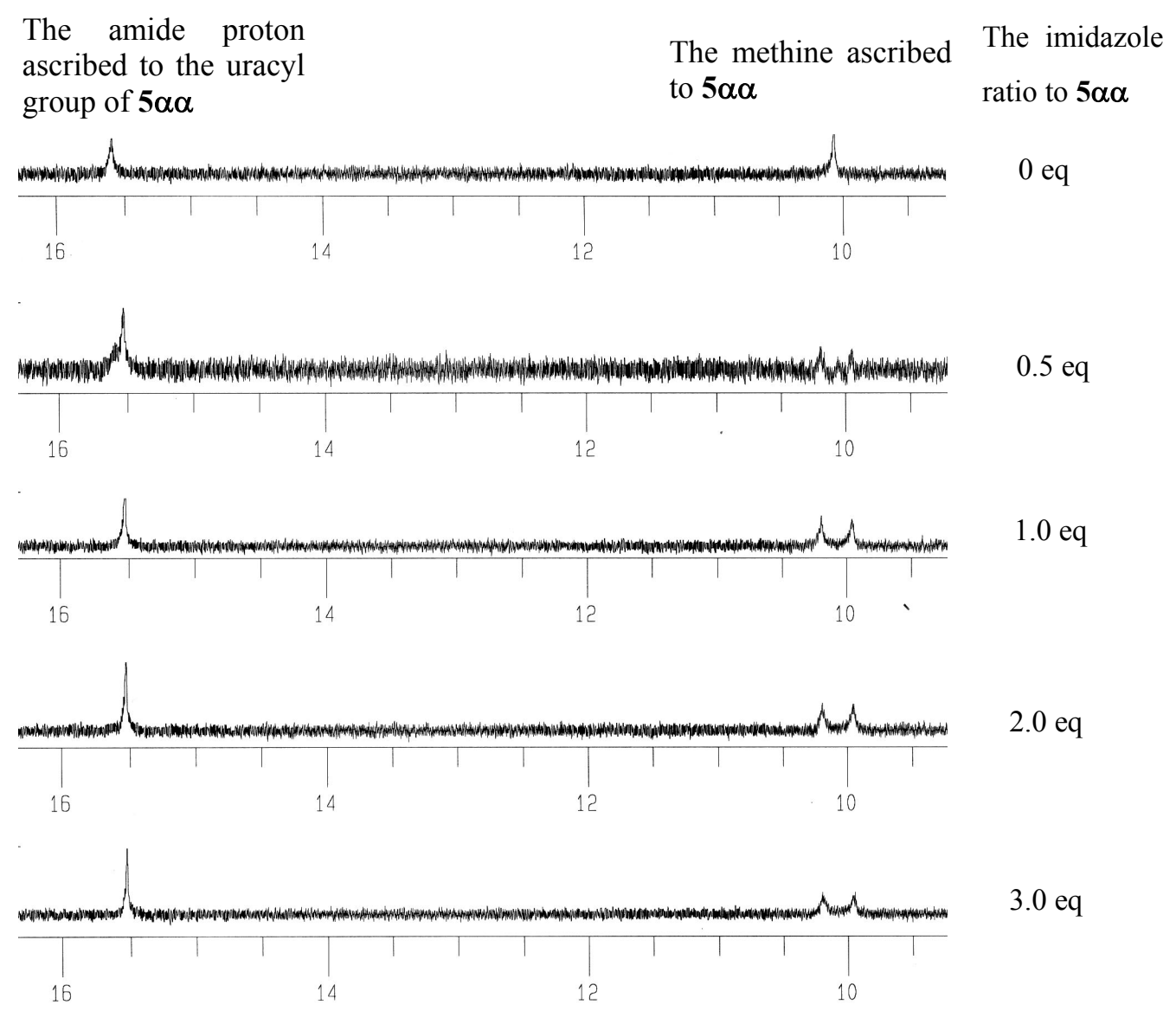

Figure S10. The titration of the imidazole solution to the dimer solution. 
The dilution experiment of the mixture of $5 \alpha \alpha(\mathbf{Z n})$ and Mela in toluene

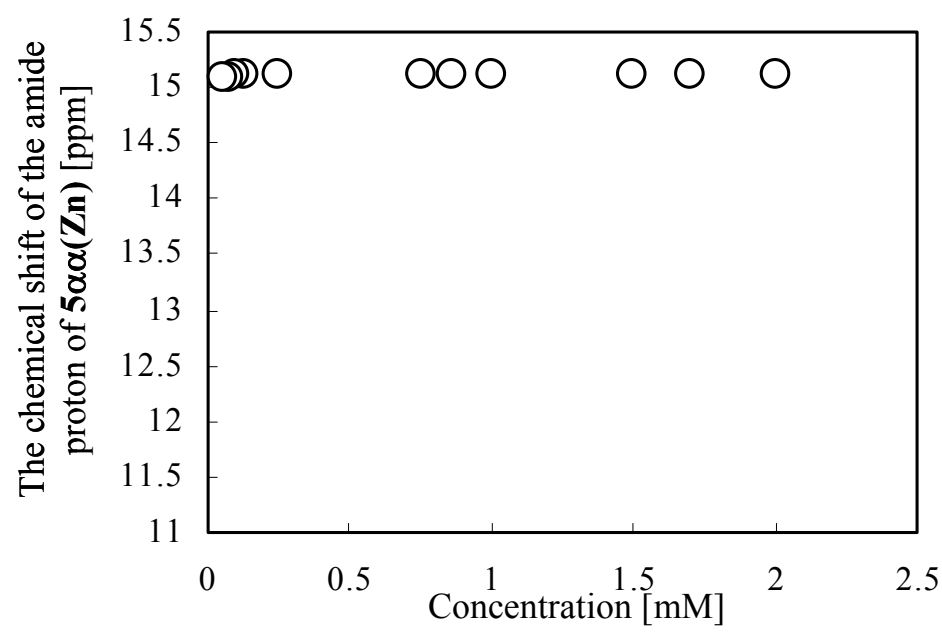

Figure S11. NMR Dilution experiment in toluene of $\mathbf{5} \alpha \boldsymbol{\alpha}(\mathbf{Z n})$ and Mela (1:1).

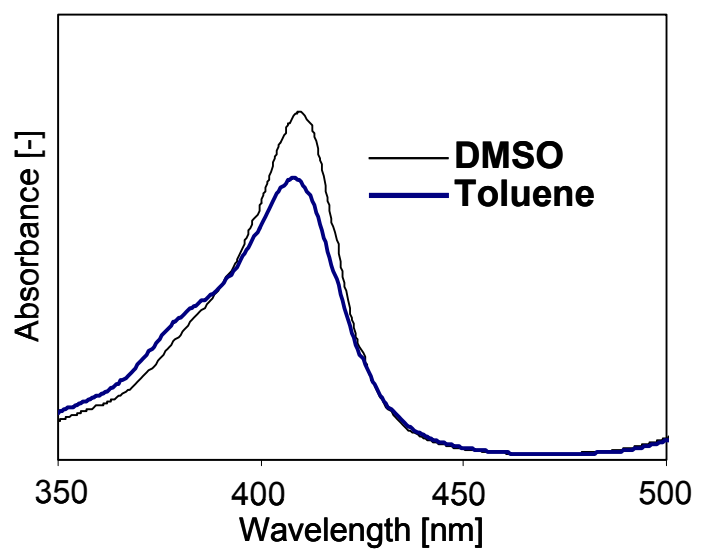

Figure S12. UV-vis spectra of 5 $\alpha \alpha$-Mela solution $1 \mathrm{mM}(0.1 \mathrm{~mm}$ path)

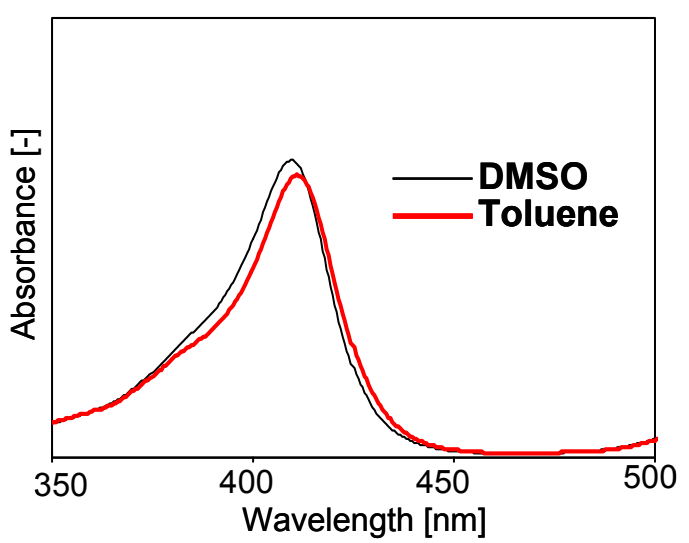

Figure S13. UV-vis spectra of 5 $\alpha \beta$-Mela solution $1 \mathrm{mM}(0.1 \mathrm{~mm}$ path) 